\title{
Modulation of Metamorphic and Regenerative Events by Cold Atmospheric Pressure Plasma Exposure in Tadpoles, Xenopus laevis
}

\author{
Ma Veronica Holganza ${ }^{1,+}$, Adonis Rivie ${ }^{2}$, Kevin Martus ${ }^{3,+}$ and and Jaishri Menon ${ }^{1, *,+}$ \\ Department of Biology, William Paterson University, Wayne, NJ 07470, USA \\ Department of Integrative Biology, University of California Berkeley, Berkeley, CA 94720, USA \\ Department of Physics, William Paterson University, Wayne, NJ 07470, USA \\ * Correspondence: menonj@wpunj.edu \\ + These authors contributed equally to this work.
}

Received: 3 June 2019; Accepted: 14 July 2019; Published: 18 July 2019

\begin{abstract}
Atmospheric pressure plasma has found wide clinical applications including wound healing, tissue regeneration, sterilization, and cancer treatment. Here, we have investigated its effect on developmental processes like metamorphosis and tail regeneration in tadpoles. Plasma exposure hastens the process of tail regeneration but delays metamorphic development. The observed differences in these two developmental processes following plasma exposure are indicative of physiological costs associated with developmental plasticity for their survival. Ultrastructural changes in epidermis and mitochondria in response to the stress of tail amputation and plasma exposure show characteristics of cellular hypoxia and oxidative stress. Mitochondria show morphological changes such as swelling with wide and fewer cristae and seem to undergo processes such as fission and fusion. Complex interactions between calcium, peroxisomes, mitochondria and their pore transition pathways are responsible for changes in mitochondrial structure and function, suggesting the subcellular site of action of plasma in this system.
\end{abstract}

Keywords: atmospheric pressure plasma; developmental plasticity; metamorphosis; mitochondria; regeneration; tadpoles; ultrastructure

\section{Introduction}

Advances and interactions between scientific fields such as biology, physics, and medicine have brought many benefits in tissue engineering and regenerative medicine. Plasma medicine, combining physics of plasma with medicine, has developed rapidly in the last few years [1] and it is the subject of this broad interdisciplinary research.

\subsection{Plasma Properties}

An ionized gas is an ensemble of positively and negatively charged particles. The term plasma was applied to these systems by Langmuir [2] and should not be confused with blood plasma. Over the past twenty years, atmospheric pressure plasmas have been the subject of numerous reviews regarding the state of the art of the devices used to generate these plasmas and characteristics of the plasmas [3-6]. In the present study, a plasma jet was used to generate a cold (low-temperature) non-equilibrium (non-thermal) atmospheric pressure plasma and will be designated as APP.

APP is a relatively new approach that is extensively studied for its biomedical applications [7]. These include sterilization, blood coagulation, cancer treatment, cell metabolism modification, hospital hygiene, antifungal treatment, dental care, skin disease and wound healing [8-13]. 
Tissue engineering and regenerative process involves a variety of cellular activities such as cell proliferation, differentiation and apoptosis. Exposure to APP promotes repair of muscle defects through control of cell proliferation and differentiation, suggesting that APP exposure has the potential for use in muscle tissue engineering and regenerative therapies [14]. APP exposure has been shown to induce differentiation and growth of developing mouse limb buds [15], as well as differentiation of bone marrow stem cells [16].

\subsection{Plasma and Reactive Oxygen Species and Reactive Nitrogen Species}

Plasma generated from atmospheric air includes reactive species mainly from $\mathrm{N}_{2}$ and $\mathrm{O}_{2}$, and may contain $\mathrm{N}, \mathrm{O}, \mathrm{O}_{3}, \mathrm{NO}, \mathrm{NO}_{2}$, and $\mathrm{OH}$. The final products of the species present in the plasma are several Reactive Oxygen Species (ROS) and Reactive Nitrogen Species (RNS). These reactive molecules expose biological material to oxidation processes [17-20]. The reactive species are generated either within the plasma itself or in the tissue when brought in contact with plasma [21]. Both ROS and RNS are also derived within the cell from organelles such as mitochondria, peroxisomes, and the endoplasmic reticulum.

ROS and RNS have pleiotropic effects on cellular physiology, which include metabolism, cellular signaling and morphogenetic processes [22,23]. At moderate concentrations, beneficial effects of ROS/RNS include defense against infectious agents, activating cellular signaling pathways and mitogenic response [24]. However, overproduction of ROS/RNS in cells or tissue can result in oxidative stress in the microenvironment of the cells [20], which can damage cell structures including lipids and membranes, proteins, and DNA [25] triggering cell death by apoptosis or necrosis [26,27]. It was also reported that exposure to plasma leads to different behaviors in cells in vitro, such as decrease in cell migration, cell detachment, apoptosis or necrosis depending on power and the exposure time [8]. APP exposure produces dose-dependent effects that range from increased cell proliferation to apoptosis including DNA damage, oxidative stress and cell cycle modification [26,28-32]. Previous studies on tadpole tail regeneration from our lab have shown that the longer exposure of the amputated tail of tadpoles Xenopus laevis to APP resulted in enhanced mortality, ascribed to increased production of $\operatorname{ROS}[33]$.

\subsection{Plasma and Wound Healing in Mammals and Amphibians}

APP exposure is also a tool that can promote wound healing and epithelial regeneration which are dynamic and complex processes involving many different types of cells. APP exposure is known to improve wound healing by its antiseptic effect, stimulation of proliferation and migration of wound related skin cells, activation or inhibition of integrin receptors on the cell surface or its angiogenic effect [34]. Appropriate doses of cold plasma have antibacterial effects, activate fibroblast proliferation in wound tissue and thus promote wound healing in mice [35]. Interaction of ROS and RNS with wounded tissue accelerates repair processes without any adverse effects on normal tissue [36].

However, mechanisms that cause adult/postnatal mammalian skin healing differ from embryonic (fetal) skin development and repair as well as from organisms such as amphibians, which regenerate their injured tissue in a process analogous to development $[37,38]$. There is no scar formation in embryonic mammalian skin [39], as well as following tail amputation in amphibians [40] in contrast to adult mammalian skin. Anuran amphibians, such as Xenopus laevis in its larval stage, can regenerate their limb and tail by means of the formation of blastema which is a mass of dedifferentiated, proliferating cells [41]. This remarkable ability of amphibians makes them a very attractive model for the study of regeneration.

\subsection{Cell Organelles, Oxidative Stress, and Apoptosis}

Mitochondria and peroxisomes are dynamic organelles that have intricate structural and functional relationships [42,43]. Both of these organelles play a key role in ROS production, which is important for cell signaling and ROS scavenging [44]. They also show high plasticity and easily 
adapt in response to developmental, metabolic and environmental alterations [42]. Peroxisomal function has long been linked to oxygen metabolism due to their high concentration of $\mathrm{H}_{2} \mathrm{O}_{2}$ generating oxidases and have several antioxidant systems, such as catalase, superoxide dismutase, peroxisomal membrane protein 20 and glutathione peroxidase [45]. Mitochondria also possess enzymes and non-enzymatic antioxidant systems [46]. Mitochondria are quantitatively the most important source of ROS, which maintain the steady-state concentration at non-toxic levels by a variety of antioxidant defenses and repair enzymes [47]. Oxidative stress is an expression used to describe various deleterious processes resulting from an imbalance between the excessive formation of ROS and limited antioxidant defenses.

Oxidative stress associated with cell death in the developing limb is due to mitochondrial production of ROS [48]. Mitochondria play a key role in apoptotic processes. The mitochondrial permeability transition pore $(\mathrm{mPTP})$ is a large conductance channel that opens in the mitochondrial membrane in response to high calcium $\left(\mathrm{Ca}^{2+}\right)$, low ATP, and oxidative stress [49-52], and opening of the MPTP causes abrupt mitochondrial depolarization. APP treatment is associated with an alteration in morphology of mitochondria, a decrease in mitochondrial membrane potential, mitochondrial enzyme activity and respiration rate in cancer cells $[18,53]$.

$\mathrm{Ca}^{2+}$, one of the most ubiquitous cellular second messengers, is also known to be involved in cell death by apoptosis, necrosis and autophagy [54]. Mitochondria are the paradigm of the double-edged sword effect of $\mathrm{Ca}^{2+}$ on cell survival and death [55]. $\mathrm{Ca}^{2+}$ overload could be detrimental to the cells as it can lead to mitochondrial depolarization, cytochrome c release, lipid peroxidation, transcription factor activation and DNA damage, resulting in apoptotic and non-apoptotic cell death [56]. Peroxisomes also play an important role in $\mathrm{Ca}^{2+}$ homeostasis.

\subsection{Developmental Plasticity in Tadpoles}

Amphibians are a group of vertebrates with a great range of developmental plasticity in their life history. Many of them maintain an aquatic larval stage of life as tadpoles that metamorphose into a terrestrial one. These organisms are also known to show adaptive developmental plasticity in response to environmental changes $[57,58]$, such as ability for accelerated metamorphosis in drying ponds. This rapid growth comes at a cost, and one such suggested cost of compensatory growth is oxidative stress due to increased ROS [59]. Environmental assessment by amphibian larvae is so well regulated that developmental acceleration can even decelerate if the conditions in the aquatic system ameliorate [58].

\subsection{Organ Regeneration in Amphibians}

The restoration of lost or damaged body parts continues to be a topic of great interest for biologists. The ability to regenerate body parts varies greatly from one species to another. This feature is extensively studied in amphibian tadpoles of the species Xenopus laevis and Xenopus tropicalis, which have remarkable abilities to regenerate their tails and limbs following amputation [60-62]. Unlike most amphibians which undergo metamorphosis, there are some species like the axolotl, which retains larval features such as external gills and undeveloped limbs throughout their life-a condition referred to as neoteny. These organisms are aquatic and fully mature but fail to metamorphose and are capable of regenerating wounds on their skin with scarless healing [40]. Increased regenerative ability of amphibians makes them excellent lab models for biomedical research, such as traumatic injury.

Most of the studies on effects of plasma are focused on tissue regeneration. The main purpose of our study is to explore the effect of plasma on organ regeneration, such as tail replacement, following amputation. Additionally, we also studied the effect of plasma on post-embryonic development, such as metamorphosis, to get insights into adaptive plasticity in these organisms to cope with oxidative stress following plasma exposure. 


\section{Materials and Methods}

\subsection{Plasma Discharge Source}

Figure 1 illustrates the geometry of the APP discharge source. The flow of high purity Helium gas (Airgas Zero Grade) was controlled over a range of 10 to 150 standard cubic centimeters per minute (sccm) by a (Cole Parmer PMR1-010537, Chicago, IL, USA) gas flowmeter and a standardized rate of $50 \mathrm{sccm}$ was used for all trials. The gas flowed through a $15 \mathrm{~cm}$ long quartz tube with an outer diameter of $6.35 \mathrm{~mm}$. A copper electrode was attached to the outer surface of the tube at a point that was $5 \mathrm{~cm}$ from the end of the tube. An alternating current power supply operating at $15 \mathrm{kHz}$ and $17 \mathrm{kV}$ was attached to the electrode. The power supply's operating parameters were controlled such that the discharge was restricted to the flow region between the electrode and the exit aperture of the tube. The resulting non-equilibrium plasma had an emission profile that indicated that $\mathrm{OH}$ radicals and molecular nitrogen was present within the tube.
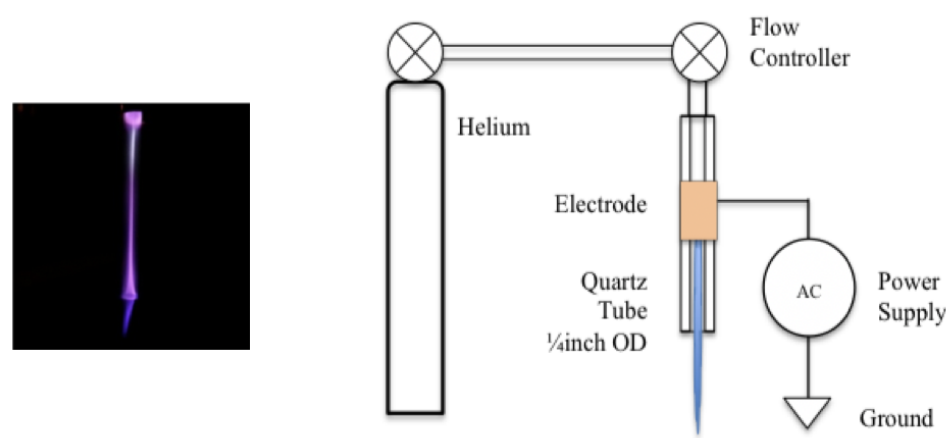

Figure 1. The plasma discharge was generated using a gas flow through a $6.35 \mathrm{~mm}$ outer diameter quartz tube with a single electrode powered by an alternating current power supply. The power supply used had a frequency of $18 \mathrm{kHz}$ and a $17 \mathrm{kV}$ peak to peak voltage. Helium was flowed through the tube at a rate of $50 \mathrm{sccm}$. The tadpoles were exposed indirectly to the glow region of the discharge, but approximately $3 \mathrm{~cm}$ beneath the tube. Inside the tube, optical emission spectroscopy confirmed that the emissions were produced by $\mathrm{OH}$ radicals and molecular nitrogen.

\subsection{Maintenance of Tadpoles}

Xenopus laevis tadpoles, purchased from Xenopus I (Ann Arbor, MI, USA) were maintained in the laboratory in aquaria and fed on a standard diet obtained from the same company. Water in the aquaria was changed on every alternate day. For the present study, the tadpoles at stage 57 were used [63] (see Appendix A for a description of stages).

\subsection{Study of Metamorphosis}

Tadpoles at stage 57 were divided in three groups of 20 each. Amputation of tail (40\% removal) and plasma exposure for $40 \mathrm{~s}$ was carried out by anesthetizing tadpoles on ice in the groups assigned below:

- Group 1: Amputated and treated with plasma and this group will be referred as experimental in the text.

- Group 2: Amputated and not treated which will be referred as control in the text.

- Group 3: This group of tadpoles were not amputated or treated with plasma to see the progress of metamorphosis which served as the control for group 2.

All the three groups were monitored for metamorphic development according to stages described by Nieukoop and Faber [63]. 


\subsection{Tail Regeneration Study}

Tadpoles at stage 57 were divided into the following two groups:

- Group 1: Tadpoles amputated and exposed to plasma as mentioned above (experimental).

- Group 2: Tadpoles amputated but not exposed to plasma (control).

For the following studies, tadpoles were anesthetized in MS222 and wound epithelium at $24 \mathrm{~h}$ and blastema at 5 days were removed from both of the groups.

\section{5. $\mathrm{Ca}^{2+}$ Quantification Assay}

$\mathrm{Ca}^{2+}$ assay was carried out using an Abcam calcium assay kit (ac102505) and quantified through microplate photometry. Wound epithelium and blastema for both of the groups were pooled from five tadpoles, as tissue from an individual tadpole was not enough for this assay (due to small size of the organism). The experiment was repeated four times $(n=4)$.

\subsection{Confocal Microscopy}

All the kits for in situ staining Calcium (F10489), peroxisomes (S34203) and mPTP (I35103) were purchased from Molecular Probes (Thermoscientific, Chicago, IL, USA). For $\mathrm{Ca}^{2+}$ staining, Fluo-4 dye is used which binds to $\mathrm{Ca}^{2+}$ exhibiting green fluorescence. mPTP staining was carried out using a calcium/cobalt quenching technique which uses calcein acetoxymethyl that enters the cell followed by treatment with cobalt chloride to quench cytosolic calcein fluorescence (green). Mitochondria are stained with Mito Tracker dye that appears red. If mPTP is compromised, calcein enters mitochondria but not the quencher. Thus, green fluorescence of the dye overlays red mitochondria producing yellow color. Peroxisome staining was carried out using antibody directed against peroxisomal membrane protein 70 (PMP70).

Tissues were harvested at $24 \mathrm{~h}$ and 5 days. For confocal imaging studies of $\mathrm{Ca}^{2+}, \mathrm{mPTP}$ and peroxisomes, three tadpoles were used for each staining procedure $(n=3)$ and carried out according to the method provided in the staining kit. Tissue samples were visualized under a Zeiss LSM 510 META Confocal microscope (Peabody, MA, USA).

\subsection{Transmission Electron Microscopy}

Tissue samples at $24 \mathrm{~h}$ and 5 days from control and experimental tadpoles $(n=3$ per time point) were fixed in $2.5 \%$ glutaraldehyde in $0.1 \mathrm{M}$ cacodyalte buffer for $24 \mathrm{~h}$, washed in the same buffer, osmicated in $1 \%$ osmium tetroxide $\left(\mathrm{OsO}_{4}\right)$, dehydrated, through a graded series of alcohol, and routinely embedded in Epon 812. Ultrathin sections in the silver gray range were cut and stained with uranyl acetate and lead citrate and observed under Hitachi 7700 (Hitachi High Technologies America, Pleasanton, CA, USA).

\section{Results}

\subsection{Metamorphic Studies}

Following tail amputation, APP exposure delayed metamorphosis compared to non-treated, see Figure 2. In group 1 (amputated and treated), all tadpoles metamorphosed by day 36 compared to group 2 (amputated and not treated), where by day 17 all of them turned into froglets. At day 10, there was a significant change between experimental and control tadpoles. There was no significant difference in the progress of metamorphosis between group 2 (amputated and not treated) and group 3 (not amputated or treated). 


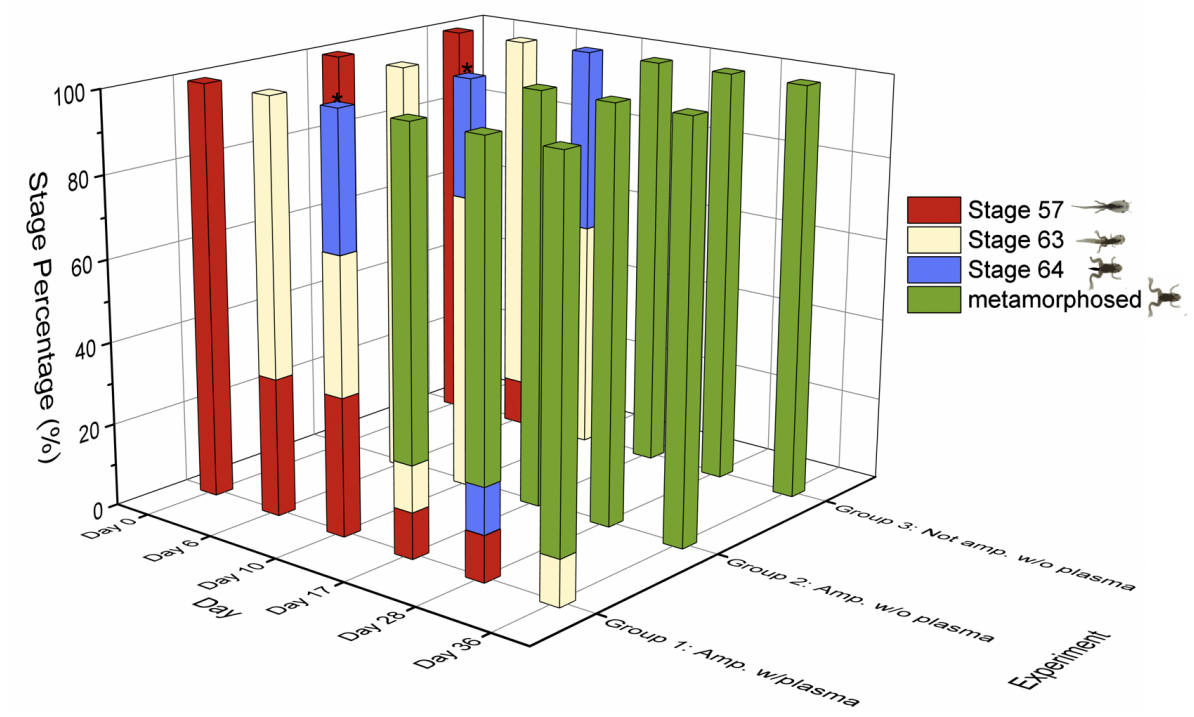

Figure 2. Graphic representation of developmental stages in metamorphosis impacted by tail amputation and plasma exposure. See Appendix A for details of developmental stages $(57,63,64)$. At stage 57, three groups of tadpoles were divided as follows: Group 1: amputated and treated with plasma (experimental tadpoles). Group 2: amputated and not treated to plasma (control tadpoles). Group 3: not amputated and not treated to plasma. At day 6, in group 1, 40\% of tadpoles were at initial stage 57 and the rest had progressed to stage 63, whereas, in group 2, all the tadpoles were at stage 63 and in group $3,90 \%$ of tadpoles were at stage 63 . At day 10 in group 1, approximately equal number of tadpoles ( 30 to $33 \%$ ) were at stage 57,63 and 64 compared to group 2 and 3, where approximately $80 \%$ of tadpoles were at stage 63 and the rest at stage 64 . By day 17 , in group 1 , an equal percentage $(15 \%)$ were at stage 57 and 63 and the rest had developed into froglets compared to groups 2 and 3 where all the tadpoles had metamorphosed into froglet. By day 36, in group 1, $90 \%$ of the tadpoles had metamorphosed into froglets.

Once the tail was amputated at stage 57 (Figure 3a), wound healing was completed by $24 \mathrm{~h}$ and a wound epithelium was formed (Figure 3c) in both the experimental and control group, subsequent to which a mass of dedifferentiated cells accumulated under the wound epithelium and by the 5th day a structure called a blastema was formed (Figure 3d,e).

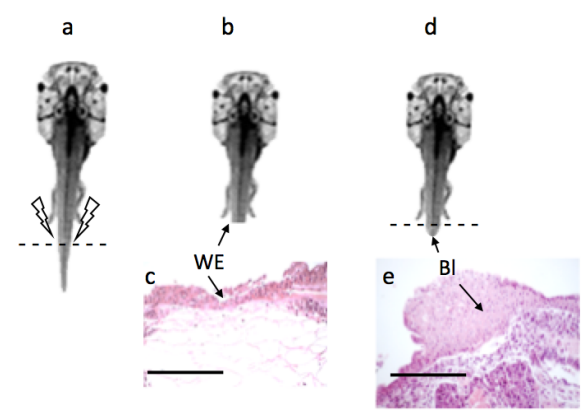

Figure 3. Wound healing and blastema formation: Following tail amputation at stage 57 (Figure 3a), wound was healed and two to three layers wound epithelium (WE) was formed in both the groups by $24 \mathrm{~h}$ (Figure 3b,c). By the 5th day, a mass of dedifferentiated cells was formed called blastema (BL) in both the groups (Figure 3d,e); scale bar $100 \mu \mathrm{m}$. However, the size of the blastema was slightly larger in the experimental group compared to the control [33]. 


\section{2. $\mathrm{Ca}^{2+}$}

In situ staining showed that, in wound epithelium at $24 \mathrm{~h}$, fluorescence intensity for $\mathrm{Ca}^{2+}$ was higher (Figure 4a) compared to control (Figure $4 b$ ). In blastema, the fluorescence intensity for $\mathrm{Ca}^{2+}$ had reduced in experimental tadpoles (Figure 4c) in comparison with control (Figure 4d).

Quantitative analysis of $24 \mathrm{~h}$ and day 5 blastema from experimental and control tadpoles showed similar results (Figure 5). However, statistically, the differences were not significant. This could be explained by the fact that, under microscope, wound epithelium and blastemal are clearly discernible from the underlying tissues. When samples were pooled from five tadpoles for quantitative analysis, it is inevitable that some of the underlying tissue like muscles would contribute to total quantity of $\mathrm{Ca}^{2+}$.

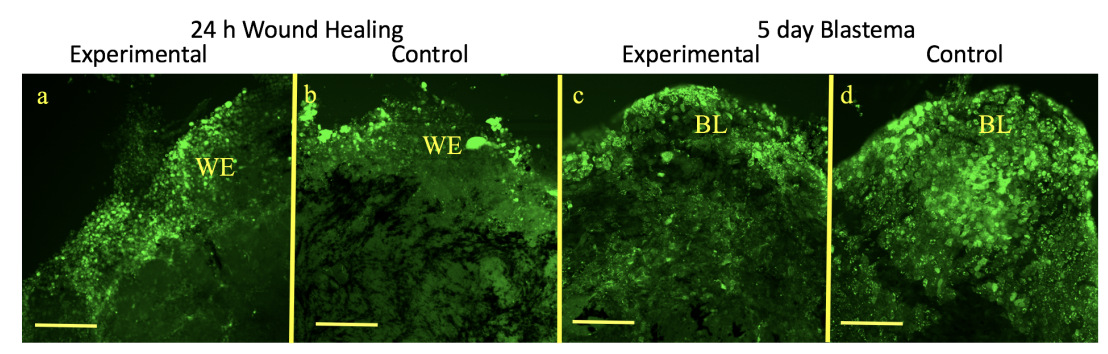

Figure 4. $\mathrm{Ca}^{2+}$ fluorescence staining: At $24 \mathrm{~h}$ post amputation, wound epithelium (WE) of experimental tadpoles show higher intensity of $\mathrm{Ca}^{2+}$ fluorescence (green) (Figure 4a) compared to control (Figure 4b). However, in day 5 blastema (BL) of experimental tadpoles, fluorescent staining was lower in Figure $4 \mathrm{c}$ compared to control Figure $4 \mathrm{~d}$; scale bar $100 \mu \mathrm{m}$.

Quantitative Assay for Calcium

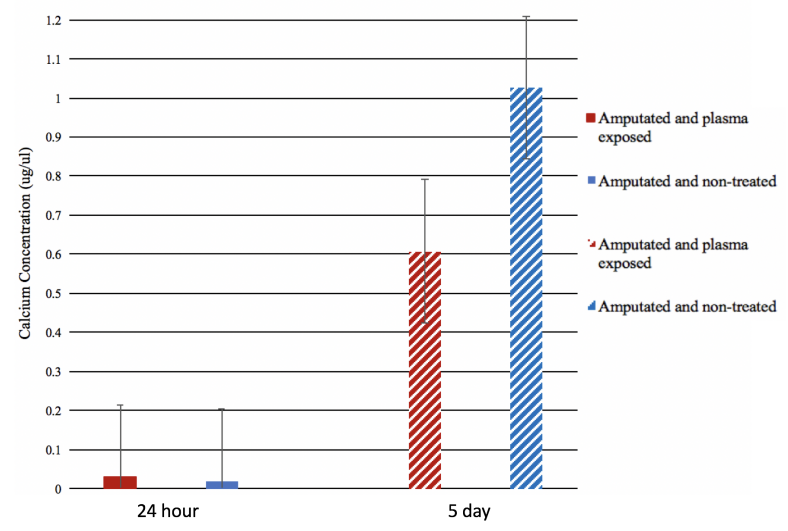

Figure 5. Quantitative $\mathrm{Ca}^{2+}$ estimation: At $24 \mathrm{~h}$ post amputation, wound epithelium (WE) of experimental and control tadpoles show lower $\mathrm{Ca}^{2+}$ content, whereas, in day 5, blastema $\mathrm{Ca}^{2+}$ content in both groups was much higher. The changes were insignificant between the two groups.

\section{3. $m P T P$}

In experimental tadpoles, at $24 \mathrm{~h}$, mitochondrial staining was prominent (Figure 6a) compared to control (Figure $6 \mathrm{~b}$ ). Similarly, the number of mitochondria and opened pores in the mitochondrial membrane of the blastema in experimental tadpoles were very distinct (Figure 6c) compared to control where there is no staining of mPTP observed (Figure 6d). 


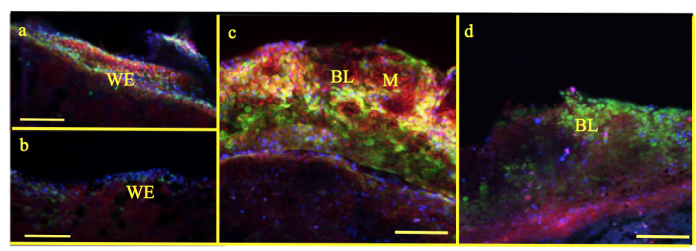

Figure 6. mPTP staining: Wound epithelium (WE) at $24 \mathrm{~h}$ as well as 5 day blastema (BL) of experimental tadpoles show increased staining for mitochondria as well as open mitochondrial pores (Figure 6a,c) compared to control (Figure 6b,d). Mitochondria (M)—red; mPTP open-yellow (calcein has entered mitochondria); calcein—green (in cytoplasm); nuclei—blue; scale bar $-100 \mu \mathrm{m}$.

\subsection{Peroxisomes}

Staining of peroxisomes in blastema of experimental tadpoles is significant (Figure 7a) compared to control, where there was negligible staining for these organelles (Figure 7b).

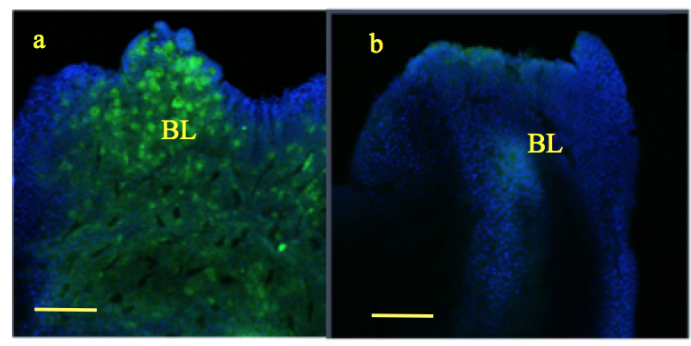

Figure 7. Increased peroxisomal staining (green) is seen in experimental tadpoles (Figure 7a) compared to control (Figure $7 \mathrm{~b}$ ). blue-nuclei. Scale bar $-100 \mu \mathrm{m}$.

\subsection{Light and Electron Microscopy}

At $24 \mathrm{~h}$, wound epithelium is formed in both the experimental and the control tadpoles (Figure 8a,b). However, there is an increased number of lipid inclusions (Figures $8 \mathrm{a}$ and $9 \mathrm{~b}$ ) and decreased visible intercellular spaces in experimental (Figures 8a and 9a) compared to control tadpoles (Figures $8 \mathrm{~b}$ and 9c). At 5 days post amputation, plasma treated tadpole tail also displayed swelling of cells and blebbing of the plasma membrane (Figure 8c,e) compared to control (Figure 8d,f).

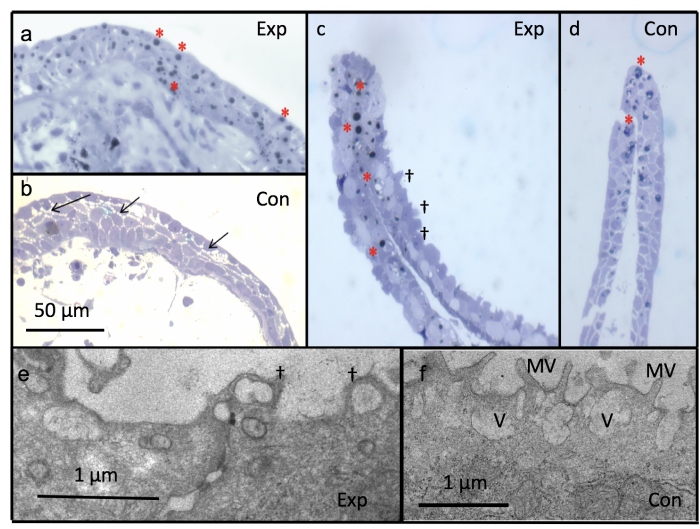

Figure 8. 1 to $1.5 \mu \mathrm{m}$ thick plastic sections showing fully formed wound epithelium after $24 \mathrm{~h}$ post amputation in experimental (Figure 8a) as well as control groups (Figure 8b). Note osmiophilic lipid bodies (red asterisk *), and decreased intercellular spaces in experimental tadpoles (Figure 8a) compared to control where intercellular spaces are visible $(\longleftarrow)$ (Figure $8 b$ ). Note blebbing $(\dagger)$ of the cells in epithelium of blastema ( 5 days) of experimental tadpoles (Figure $8 \mathrm{c}$ ) compared to control (Figure 8d). Ultrastructural studies; Figure 8e,f: Transmission electron micrograph of wound epithelium of experimental tadpoles shows loss of microvilli and blebbing $(\dagger)$ (Figure 8e) in contrast to control (Figure 8f). (Figure 8a-d from Rivie et al. [33]). Exp-experimental; Con-control. 
At $24 \mathrm{~h}$ post amputation, tail epidermis of experimental tadpoles revealed loss of microvilli (Figure 9a,b) compared to control (Figure 9c,d). Mitochondria of wound epithelium at $24 \mathrm{~h}$ of the experimental tadpoles shows loss of cristae (Figure 9e) and fusion of mitochondria with wide cristae (Figure 10a,b) compared to control where mitochondria are small and round with thin cristae (Figure 9d,f). Additionally, in experimental tadpoles, the mitochondrial matrix is electro-lucent (Figure 10a,c) compared to control (Figure 10d). Close proximity of mitochondria with endoplasmic reticulum is seen in experimental (Figure 10c) and control (Figure 10d) tadpoles.

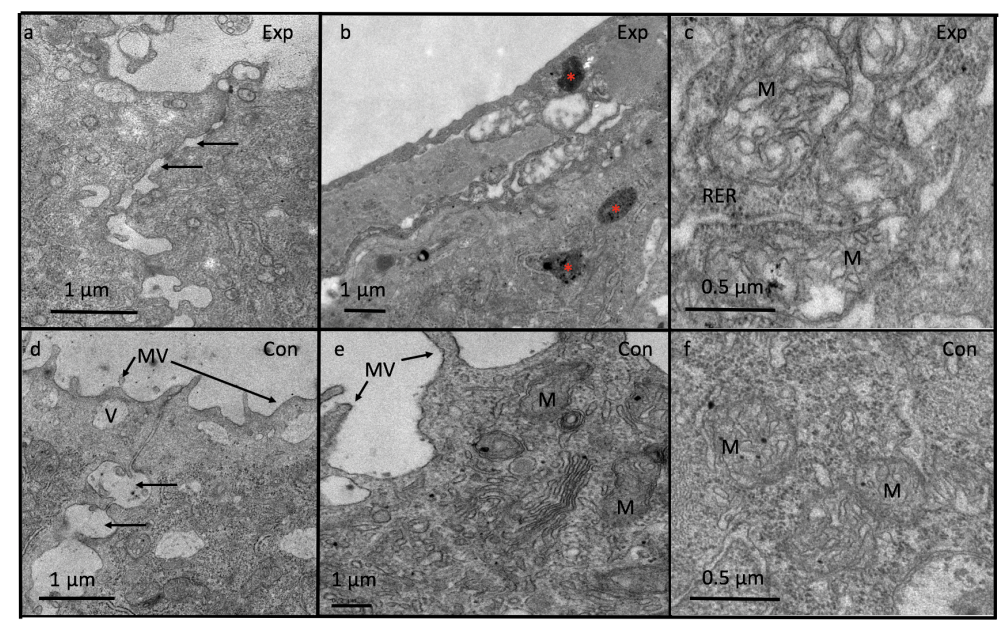

Figure 9. Ultrastructure of wound epithelium at $24 \mathrm{~h}$ post amputation showing loss of microvilli (MV), decreased intercellular spaces $(\longleftarrow)$ (Figure 9a) and increased number of lipid inclusions $\left(^{*}\right.$ ) (Figure 9b) compared to control where microvilli (MV) and intercellular spaces $(\longleftarrow-$ ) are prominent (Figure 9c,d). In experimental tadpoles, mitochondria are swollen and fused with wide cristae (Figure 9e) compared to control (Figure 9f). Exp-experimental; Con-control.

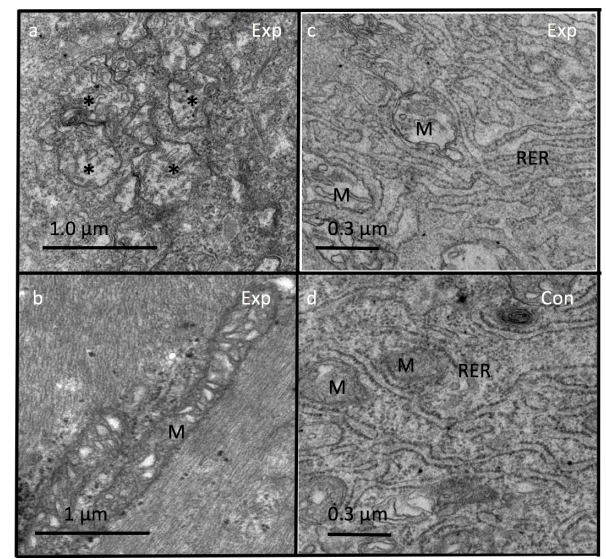

Figure 10. Ultrastructure of blastema from experimental tadpoles after 5 days showing fusion of damaged mitochondria $(\mathrm{M})$ with near loss of cristae (Figure 10a) and often very long mitochondria due to fusion (Figure 10b). Mitochondria (M) from plasma-exposed tadpoles have an electro-lucent matrix (Figure 10c) compared to control (Figure 10d). Note close proximity of endoplasmic reticulum (RER) and mitochondria in both of the groups (Figure 10c,d). Exp-experimental; Con-control.

\section{Discussion}

\subsection{Adaptive Plasticity}

Earlier studies [33] and current results indicate that the plasma treatment accelerates tail regeneration of tadpoles Xenopus laevis while slowing down the metamorphic progress. This is an example of adaptive plasticity, essential for many species to cope with changes in the environment. 
Many amphibian species have exploited this trait by accelerating metamorphic events when threatened by desiccation in their aquatic habitat $[58,64]$. Increased oxidative stress is considered a key determinant factor for accelerated growth and metamorphosis [65]. The most important environmental adaptation for tadpoles is swimming in water for their survival [66]. In the current study, the tadpole tail was amputated and exposed to plasma at a stage when hind limbs had not yet fully developed and forelimbs had not erupted (stage 57). Hence, these tadpoles are subjected to two kinds of stress: (a) removal of the tail hampers their locomotor ability (movement in water) and (b) the stress of plasma exposure. Restriction of swimming activity in the absence of fully developed limbs contributes to a faster rate of tail regeneration for their survival but is achieved at the expense of metamorphosis. One can argue that these tadpoles can hasten the process of metamorphosis instead of regenerating their tail. However, accelerated metamorphosis cannot take place until the animal has reached a threshold developmental stage $[67,68]$. Cost of faster growth of the regenerating tail in these tadpoles following plasma exposure is associated with increased oxidative stress trade-offs. Differences observed in tail regeneration and metamorphosis between experimental and control tadpoles indicate the physiological cost involving metabolic machinery at the cellular and organelle level. However, in the absence of plasma treatment, there was no significant difference in metamorphic growth between amputated and non-amputated group of tadpoles. This means that plasma exposure might be increasing the signaling for tail regeneration via bone morphogenetic protein and Notch, which act as mitogenic factors in Xenopus organ regeneration as reported by Beck et al. [62]. This topic remains to be explored following plasma treatment.

\subsection{Tail Regeneration}

The tail of Xenopus tadpole is efficient in regenerating all the competent tissues after amputation, including spinal cord, notochord, muscles and epidermis. Upon amputation of the tail, the wound is healed within $24 \mathrm{~h}$ and a population of progenitor cells are produced known as the blastema. Blastema is a mass of dedifferentiated pluripotent cells that is able to form multiple tissue types following the amputation and wound healing occurring [69-71]. The process of tadpole tail regeneration is considered analogous to tissue renewal in mammals [72]. Analogies have also been drawn between cells undergoing regeneration in salamanders and stem cells [73].

Our previous and current observations have shown that plasma exposure accelerates the process of regeneration in tadpoles, Xenopus laevis, and it was interesting that, under APP exposure, local oxidative stress was higher compared to control [33]. Tadpoles' capacity to adaptively tune to tail regeneration is controlled by several factors-one of them being oxidative stress. Moderate levels of ROS act as signaling molecules during tail regeneration in Xenopus [61,74]. Wounding tissue generates ROS especially $\mathrm{H}_{2} \mathrm{O}_{2}$ [75], which freely diffuses between cells and acts as a signaling molecule during early phases of regeneration and blastema formation in adult fin regeneration of zebrafish [76].

\section{3. $\mathrm{Ca}^{2+}$, Endoplasmic Reticulum (ER), Mitochondria and Peroxisomes}

$\mathrm{Ca}^{2+}$ is an important second messenger and plays a critical role in the fate of the cell surviving or dying. Currently, we have an observed increase in $\mathrm{Ca}^{2+}$ with confocal microscopy during wound healing ( $24 \mathrm{~h}$ post amputation) but a decrease in day 5 blastema. It is possible that increased $\mathrm{Ca}^{2+}$ content derived from intracellular $\mathrm{Ca}^{2+}$ stores, such as ER, following plasma exposure might be responsible for apoptosis of damaged cells during the wound healing period. Low $\mathrm{Ca}^{2+}$ in the blastema of experimental tadpoles may support early differentiation of these cells as reported in mammalian epidermal cells [77], resulting in faster tail regeneration in experimental tadpoles.

Additionally, the relationship between $\mathrm{Ca}^{2+}$ and $\mathrm{ROS}$ is complicated and close, either as a crucial partner in regulating the redox status of cells, determining cell fate, or in signaling in response to a number of physiological and stress conditions [78]. Our studies find support from the work of Ma et al. [29] that an increase in intracellular ROS [33] and $\mathrm{Ca}^{2+}$ following APP exposure (current study) could serve as valuable biomarkers for the oxidative stress. 
Mitochondria also undergo remodeling of their shape and morphology during programmed cell death-a biological process that usually confers an advantage during an organism's life-cycle. Mitochondria are dynamic organelles that continually undergo fusion and fission. These are two opposing processes that act in concert to maintain the shape, size, and number of mitochondria as well as their physiological function [79]. Our electron microscopy study shows that some mitochondria from experimental tadpoles had fused acquiring elongated or giant shapes with wide cristae compared to controls where mitochondria were round, smaller and with thin cristae. A high level of stress leads to fission of mitochondria, which would eliminate damaged mitochondria through mitophagy [80]. Mitochondrial fission also inhibits propagation of the $\mathrm{Ca}^{2+}$ signal and protects against $\mathrm{Ca}^{2+}$ mediated cell death [81], whereas mitochondrial fusion allows them to compensate for one another's defects by sharing components, in order to maintain energy output in stressful situations $[82,83]$. Fission and fusion interact to create a diversity of mitochondrial structures and ER may play an active role in determining the sites of mitochondrial fission [84]. Additionally, in experimental tadpoles, some mitochondria were swollen with an electro-lucent matrix compared to control, which could be due to ischemia [85], increased $\mathrm{Ca}^{2+}$ overload [18,55], and induction of mPTP [86]. Increase in $\mathrm{Ca}^{2+}$ (as observed using the confocal microscopy), as well as oxidative stress [33] in the regenerated tissue following plasma exposure, might be responsible for the opening of $\mathrm{MPTP}$, which changes mitochondrial morphology as reported by Fridman and Lowe [87]. Currently observed changes in mitochondrial dynamics may allow cells to adapt to oxidative stress which warrants further studies.

ER is also known to generate peroxisomes [88]. Currently, an observed increase in peroxisomes in blastema of experimental tadpoles might be generating and releasing important signal molecules; such as, $\mathrm{O}_{2}^{-}, \mathrm{H}_{2} \mathrm{O}_{2}$ and $\mathrm{NO}$ in cytosol, which can contribute to a more integrated communication system among cell compartments as reported by Corpas et al. [89]. Additionally, peroxisomes must be providing protective mechanisms to counteract oxidative stress.

\subsection{Ultrastructure of Tadpole Epidermis (Epidermal Morphology and Junctional Complex)}

The epidermis of vertebrates is the principal barrier against environmental stress. Higher vertebrates have specific detoxifying molecules and enzymes involved in providing protection to the organisms. The importance of tight junctions in barrier formation in mammals is very well documented [90]. However, amphibian epidermis does not have as good a barrier mechanism as in higher vertebrates. However, they do possess complex junctional systems that help to decrease trans-epidermal water loss [91] and maintain skin integrity by preventing toxic, infectious or traumatic stress [92]. In the current study, we have observed adherens junctions (possibly including tight junctions) between epidermal cells of the tail and reduction of intercellular spaces at $24 \mathrm{~h}$ post amputation and following plasma exposure. Cellular junctions do not function independently and it is reported that junctional crosstalk, interdependencies, and compensation are necessary for tissue strength [93]. Since tadpoles do not have a good barrier on skin surface, this means that the tension is likely to be in the underlying epidermis. Additionally, the outer surface of the epidermis is exposed to the external environment, and the animal has to prevent the loss of molecules from the cells, which probably resulted in the loss of microvilli and formation of tight junctions between the epidermal cells following plasma exposure. These morphological changes in the epidermis following plasma exposure indicate adaptive changes in order to maintain skin integrity.

\section{Conclusions}

APP exposure affects wound healing and tail regeneration in larval tadpoles. The APP exposure stimulates multiple signaling cellular pathways coordinating the morphogenetic processes that underlie regeneration and metamorphosis, which in turn influences developmental plasticity of these organisms. Currently, we are extending this work, evaluating gene expression for antioxidant enzymes superoxide dismutase and catalase, as well as bone morphogenetic protein, a factor required for regeneration and metamorphosis. 
Author Contributions: K.M. and J.M. conceptualized the idea. K.M. designed and tested the plasma source. J.M. planned the experiments. M.V.H. and A.R. carried out the experiments on the confocal microscope. M.V.H. analyzed and processed the experimental results and contributed to the interpretation of results. J.M. carried out the ultrastructural studies. J.M. and K.M. took the lead in writing the manuscript in consultation with M.V.H.

Funding: This research received no external funding.

Acknowledgments: K.M. and J.M. support through the William Paterson University Assigned Released Program and Student Worker Fund. M.V.H. and A.R. supported through the Garden State Louis Stokes Alliance for Minority Participation (GS-LSAMP). Figure 8a-d are reprinted by permission from Springer Nature, The European Physical Journal-Special Topics, Atmospheric pressure plasma accelerates tail regeneration in tadpoles Xenopus laevis, Rivie, Martus, Menon (2017) [33].

Conflicts of Interest: The authors declare no conflict of interest.

\section{Abbreviations}

The following abbreviations are used in this manuscript:

$\begin{array}{ll}\text { APP } & \text { Atmospheric Pressure Plasma } \\ \text { BL } & \text { Blastema } \\ \text { ER } & \text { Endoplasmic Reticulum } \\ \text { M } & \text { Mitochondria } \\ \text { mPTP } & \text { mitochondrial Permeability Transition Pore } \\ \text { MV } & \text { Microvilli } \\ \text { ROS } & \text { Reactive Oxygen Species } \\ \text { RNS } & \text { Reactive Nitrogen Species } \\ \text { RER } & \text { Rough Endoplasmic Reticulum } \\ \text { sccm } & \text { standard cubic centimeters per minute } \\ \text { WE } & \text { Wound Epithelium }\end{array}$

\section{Appendix A}

Tadpole development by stages from Nieukoop and Faber [63]. Stage 57: Lateral view of the tadpoles showing hind limbs $(\longleftarrow)$ in early developmental stage and forelimbs have not erupted. Stage 63: Dorsal view of the tadpole showing well developed hind limbs and erupted forelimbs. Stage 64: Dorsal view of tadpole tail regression.

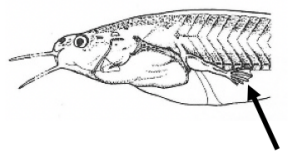

57

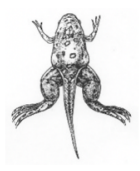

63

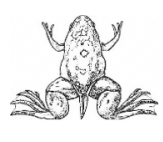

64

Figure A1. Tadpole development by stages. Hind limbs stage 57 denoted by $\longleftarrow$.

\section{References}

1. von Woedtke, T.; Metelmann, H.R.; Weltmann, K.D. Clinical plasma medicine: State and perspectives of in vivo application of cold atmospheric plasma. Contrib. Plasma Phys. 2014, 54, 104-117. [CrossRef]

2. Langmuir, I. Oscillations in ionized gases. Proc. Natl. Acad. Sci. USA 1928, 14, 627-637. [CrossRef] [PubMed]

3. Schütze, A.; Jeong, J.Y.; Babayan, S.E.; Park, J.; Selwyn, G.S.; Hicks, R.F. The atmospheric-pressure plasma jet: A review and comparison to other plasma sources. IEEE Trans. Plasma Sci. 2006, 26, 1685-1694. [CrossRef]

4. Winter, J.; Brandenburg, R.; Weltmann, K.D. Atmospheric pressure plasma jets: An overview of devices and new directions. Plasma Sources Sci. Technol. 2015, 24, 064001. [CrossRef]

5. Bruggeman, P.J.; Iza, F.; Brandenburg, R. Foundations of atmospheric pressure non-equilibrium plasmas. Plasma Sources Sci. Technol. 2017, 26, 123002. [CrossRef]

6. Tendero, C.; Tixier, C.; Tristant, P.; Desmaison, J.; Leprince, P. Atmospheric pressure plasmas: A review. Spectrochim. Acta Part B At. Spectrosc. 2006, 21, 2-30. [CrossRef] 
7. Park, G.Y.; Park, S.J.; Choi, M.Y.; Koo, I.G.; Byun, J.H.; Hong, J.W.; Sim, J.Y.; Collins, G.J.; Lee, J.K. Atmospheric-pressure plasma sources for biomedical applications. Plasma Sources Sci. Technol. 2012, 21, 043001. [CrossRef]

8. Hoffmann, C.; Berganza, C.; Zhang, J. Cold atmospheric plasma: Methods of production and application in dentistry and oncology. Med. Gas Res. 2013, 3, 21. [CrossRef]

9. Fridman, G.; Friedman, G.; Gutsol, A.; Shekhter, A.; Vasilets, V.; Fridman, A. Applied plasma medicine. Plasma Process. Polym. 2008, 5, 503-533. [CrossRef]

10. Laroussi, M. Plasma medicine: A brief introduction. Plasma 2018, 1, 47-60. [CrossRef]

11. Morfill, G.; Kong, M.; Zimmermann, J. Focus on plasma medicine. New J. Phys. 2009, 11, 115011. [CrossRef]

12. Kong, M.G.; Kroesen, G.; Morfill, G.; Nosenko, T.; Shimizu, T.; Van Dijk, J.; Zimmermann, J.L. Plasma medicine: An introductory review. New J. Phys. 2009, 11, 115012. [CrossRef]

13. Tanaka, H.; Hori, M. Medical applications of non-thermal atmospheric pressure plasma. J. Clin. Biochem. Nutr. 2017, 60, 29-32. [CrossRef] [PubMed]

14. Choi, J.W.; Kang, S.U.; Kim, Y.E.; Park, J.K.; Yang, S.S.; Kim, Y.S.; Lee, Y.S.; Lee, Y.; Kim, C.-H. Novel therapeutic effects of non-thermal atmospheric pressure plasma for muscle regeneration and differentiation. Sci. Rep. 2016, 6, 28829. [CrossRef] [PubMed]

15. Chernets, N.; Zhang, J.; Steinbeck, M.J.; Kurpad, D.S.; Koyama, E.; Friedman, G.; Freeman, T.A. Nonthermal atmospheric pressure plasma enhances mouse limb bud survival, growth, and elongation. Tissue Eng. Part A 2015, 21, 300-309. [CrossRef] [PubMed]

16. Wang, M.; Cheng, X.; Zhu, W.; Holmes, B.; Keidar, M.; Zhang, L.G. Design of biomimetic and bioactive cold plasma-modified nanostructured scaffolds for enhanced osteogenic differentiation of bone marrow-derived mesenchymal stem cells. Tissue Eng. Part A 2013, 20, 1060-1071. [CrossRef]

17. Haertel, B.; Hahnel, M.; Blackert, S.; Wende K.; von Woedtke, T.; Lindequist U. Surface molecules on HaCaT keratinocytes after interaction with non-thermal atmospheric pressure plasma. Cell Biol. Int. 2012, 36, 1217-1222. [CrossRef]

18. Panngom, K.; Baik, K.Y.; Nam, M.K.; Han, J.H.; Rhim, H.; Choi, E.H. Preferential killing of human lung cancer cell lines with mitochondrial dysfuction by nonthermal dielectric barrier discharge plasma. Cell Death Dis. 2013, 4, e642. [CrossRef]

19. Schmidt, A.; Dietrich, S.; Steuer, A.; Weltmann, K.D.; von Woedtke, T.; Masur, K.; Wende, K. Non-thermal plasma activates human keratinocytes by stimulation of antioxidant and phase II pathways. J. Biol. Chem. 2015, 290, 6731-6750. [CrossRef]

20. Wende, K.; Straßenburg, S.; Haertel, B.; Harms, M.; Holtz, S.; Barton, A.; Masur, K.; von Woedtke, T.; Lindequist, U. Atmospheric pressure plasma jet treatment evokes transient oxidative stress in HaCaT keratinocytes and influences cell physiology. Cell Biol. Int. 2014, 38, 412-425. [CrossRef]

21. Georgescu, N.; Lupu, A.R. Tumoral and normal cells treatment with high-voltage pulsed cold atmospheric plasma jets. IEEE Trans. Plasma Sci. 2010, 38, 1949-1955. [CrossRef]

22. Finkel, T.; Holbrook, N.J. Oxidants, oxidative stress and the biology of ageing. Nature 2000, 10, 142-149. [CrossRef] [PubMed]

23. Lambeth, J.D. NOX enzymes and the biology of reactive oxygen. Nat. Rev. Immunol. 2004, 4, 181-189. [CrossRef] [PubMed]

24. Valko, M.; Leibfritz, D.; Moncol, J.; Cronin, M.T.; Mazur, M.; Telser, J. Free radicals and antioxidants in normal physiological functions and human disease. Int. J. Biochem. Cell Biol. 2007, 39, 44-84. [CrossRef] [PubMed]

25. Kim, S.J.; Chung, T.H. Cold atmospheric plasma-jet generated RONS and their selective effects on normal and carcinoma cells. Sci. Rep. 2008, 6, 20332. [CrossRef] [PubMed]

26. Fridman, G.; Shereshevsky, A.; Jostet, M.M. Floating electrode dielectric barrier discharge plasma in air promoting apoptotic behavior in melanoma skin cancer cell lines. Plasma Chem. Plasma Process. 2007, 27, 163-176. [CrossRef]

27. Barekzi, N.; Laroussi, M. Dose-dependent killing of leukemia cells by low-temperature plasma. J. Phys. D Appl. Phys. 2012, 45, 422002. [CrossRef]

28. Kalghatgi, S.U.; Fridman, G.; Cooper, M.; Nagaraj, G.; Peddinghaus, M.; Balasubramanian, M.; Vasilets, V.N.; Gutsol, A.F.; Fridman, A.; Friedman, G. Mechanism of blood coagulation by nonthermal atmospheric pressure dielectric barrier discharge plasma. IEEE Trans. Plasma Sci. 2007, 35, 1559-1566. [CrossRef] 
29. Ma, R.N.; Feng, H.Q.; Liang, Y.D.; Zhang, Q.; Tian, Y.; Su, B.; Zhang, J.; Fang, J. An atmospheric-pressure cold plasma leads to apoptosis in Saccharomyces cerevisiae by accumulating intracellular reactive oxygen species and calcium. J. Phys. D Appl. Phys. 2013, 46, 285401-285408. [CrossRef]

30. Keidar, M.; Walk, R.; Shashurin, A.; Srinivasan, P.; Sandler, A.; Dasgupta, S.; Ravi, R.; Guerrero-Preston, R.; Trink, B. Cold plasma selectivity and the possibility of a paradigm shift in cancer therapy. Br. J. Cancer 2011, 105, 1295. [CrossRef]

31. Lee, H.J.; Shon, C.H.; Kim, Y.S.; Kim, S.; Kim, G.C.; Kong, M.G. Degradation of adhesion molecules of G361 melanoma cells by a non-thermal atmospheric pressure microplasma. New J. Phys. 2009, 11, 115026. [CrossRef]

32. Kim, G.C.; Kim, G.J.; Park, S.R.; Jeon, S.M.; Seo, H.J.; Iza, F.; Lee, J.K. Air plasma coupled with antibody-conjugated nanoparticles: A new weapon against cancer. J. Phys. D 2008, 10, 032005. [CrossRef]

33. Rivie, A.; Martus, K.; Menon, J. Atmospheric pressure plasma accelerates tail regeneration in tadpoles Xenopus laevis. J. Eur. Phys. J. Spec. Top. 2017, 226, 2859-2871. [CrossRef]

34. Haertel, B.; Von Woedtke, T.; Weltmann, K.D.; Lindequist, U. Non-thermal atmospheric-pressure plasma possible application in wound healing. Biomol. Ther. 2014, 22, 477-490. [CrossRef] [PubMed]

35. Xu, G.M.; Shi, X.M.; Cai, J.F.; Chen, S.L.; Li, P.; Yao, C.W.; Chang, Z.S.; Zhang, G.J. Dual effects of atmospheric pressure plasma jet on skin wound healing of mice. Wound Repair Regen. 2015, 23, 878-884. [CrossRef] [PubMed]

36. Fathollah, S.; Mirpour, S.; Mansouri, P.; Dehpour, A.R.; Ghoranneviss, M.; Rahimi, N.; Safaie Naraghi, Z.; Chalangari, R.; Chalangari, K.M. Investigation on the effects of the atmospheric pressure plasma on wound healing in diabetic rats. Sci. Rep. 2016, 6, 19144. [CrossRef] [PubMed]

37. McCallion, R.L.; Ferguson, M.W.J. Fetal wound healing and the development of antiscarring therapies for adult wound healing. In The Molecular and Cellular Biology of Wound Repair; Clark, R., Ed.; Springer: Boston, MA, USA, 1988; pp. 561-600, ISBN 978-1-4899-0185-9.

38. Dudas, M.; Wysocki, A.; Gelpi, B.; Tuan, T.L. Memory encoded throughout our bodies: Molecular and cellular basis of tissue regeneration. Pediatr. Res. 2008, 63, 502-512. [CrossRef]

39. Takeo, M.; Lee, W.; Ito, M. Wound healing and skin regeneration. Cold Spring Harb. Perspect. Med. 2015, 5, a023267. [CrossRef]

40. Bielefeld, K.A.; Amini-Nik, S.; Alman, B.A. Cutaneous wound healing: Recruiting developmental pathways for regeneration. Cell. Mol. Life Sci. 2013, 10, 2059-2081. [CrossRef]

41. Beck, C.W.; Christen, B.; Slack, J.M. Beyond early development: Xenopus as an emerging model for the study of regenerative mechanisms. Dev. Dyn. 2009, 238, 1226-1248. [CrossRef]

42. Demarquoy, J.; Le Borgne, F. Crosstalk between mitochondria and peroxisomes. World J. Biol. Chem. 2015, 6, 301-309. [CrossRef] [PubMed]

43. Schrader, M.; Yoon, Y.T. Mitochondria and peroxisomes: Are the "Big Brother" and the "Little Sister" closer than assumed? BioEssays 2007, 29, 1105-1114. [CrossRef] [PubMed]

44. Matés, J.M.; Segura, J.A.; Alonso, F.J.; Márquez, J. Oxidative stress in apoptosis and cancer: An update. Arch. Toxicol. 2012, 11, 1649-1665. [CrossRef] [PubMed]

45. Bonekamp, N.A.; Völkl, A.; Fahimi, H.D.; Schrader, M. Reactive oxygen species and peroxisomes: Struggling for balance. BioFactors 2009, 35, 346-355. [CrossRef] [PubMed]

46. Andreyev, A.Y.; Kushnareva, Y.E.; Starkov, A.A. Mitochondrial metabolism of reactive oxygen species. Biochemistry 2005, 70, 200-214. [CrossRef] [PubMed]

47. Turrens, J.F. Mitochondrial formation of reactive oxygen species. J. Physiol. 2003, 552, 335-344. [CrossRef] [PubMed]

48. Salas-Vidal, E.; Lomeli, H.; Castro-Obregon, S.; Cuervo, R.; Escalante-Alcalde, D.; Covarrubias, L. Reactive oxygen species participate in the control of mouse embryonic cell death. Exp. Cell Res. 1998, 238, 136-147. [CrossRef] [PubMed]

49. Duchen, M.R. Roles of mitochondria in health and disease. Diabetes 2004, 53, S96-S102. [CrossRef] [PubMed]

50. Baumgartner, H.K.; Gerasimenko, J.V.; Thorne, C.; Ferdek, P.; Pozzan, T.; Tepikin, A.V.; Petersen, O.H.; Sutton, R.; Watson, A.J.; Gerasimenko, O.V. Calcium elevation in mitochondria is the main $\mathrm{Ca}^{2+}$ requirement for mitochondrialpermeability transition pore (mPTP) opening. J. Biol. Chem. 2009, 284, 20796-20803. [CrossRef] 
51. Bonora, M.; Wieckowski, M.R.; Chinopoulos, C.; Kepp, O.; Kroemer, G.; Galluzzi, L.; Pinton, P. Molecular mechanisms of cell death: Central implication of ATP synthase in mitochondrial permeability transition. Oncogene 2015, 34, 1475-1486. [CrossRef]

52. Morciano, G.; Giorgi, C.; Bonora, M.; Punzetti, S.; Pavasini, R.; Wieckowski, M.R.; Campo, G.; Pinton, P. Molecular identity of the mitochondrial permeability transition pore and its role in ischemia-reperfusion injury. J. Mol. Cell. Cardiol. 2015, 78, 142-153. [CrossRef] [PubMed]

53. Chen, G.; Wang, F.; Trachootham, D.; Huang, P. Preferential killing of cancer cells with mitochondrial dysfunction by natural compounds. Mitochondrion 2011, 10, 614-625. [CrossRef] [PubMed]

54. Zhivotovsky, B.; Orrenius, S. Calcium and cell death mechanisms. A perspective from the cell death community. Cell Calcium 2011, 50, 211-221. [CrossRef] [PubMed]

55. Pinton, P.; Giorgi, C.; Siviero, R.; Zecchini, E.; Rizzuto, R. Calcium and apoptosis: ER-mitochondria Ca ${ }^{2+}$ transfer in the control of apoptosis. Oncogene 2008, 27, 6407-6418. [CrossRef]

56. Yan, Y.; Wei, C.; Zhang, W.; Cheng, H.; Liu, J. Cross-talk between calcium and reactive oxygen species signaling. Acta Pharmacol. Sin. 2006, 27, 821-826. [CrossRef]

57. Burraco, P.; Valdés, A.E.; Johansson, F.; Gomez-Mestre, I. Physiological mechanisms of adaptive developmental plasticity in Rana temporaria island populations. BMC Evol. Biol. 2017, 17, 164. [CrossRef]

58. Gomez-Mestre, I.; Kulkarni, S.; Buchholz, D.R. Mechanisms and consequences of developmental acceleration in tadpoles responding to pond drying. PLoS ONE 2013, 8, e84266. [CrossRef]

59. Mangel, M.; Munch, S.B. A life-history perspective on short-and long-term consequences of compensatory growth. Am. Nat. 2005, 166, E155-E176. [CrossRef]

60. Slack, J.M.; Lin, G.; Chen, Y. The Xenopus tadpole: A new model for regeneration research. Cell Mol. Life Sci. 2008, 65, 54-63. [CrossRef]

61. Love, N.R.; Chen, Y.; Ishibashi, S.; Kritsiligkou, P.; Lea, R.; Koh, Y.; Gallop, J.L.; Dorey, K.; Amaya, E. Amputation-induced reactive oxygen species are required for successful Xenopus tadpole tail regeneration. Nat. Cell Biol. 2013, 15, 222-228. [CrossRef]

62. Beck, C.W.; Christen, B.; Barker, D.; Slack, J.M. Temporal requirement for bone morphogenetic proteins in regeneration of the tail and limb of Xenopus tadpoles. Mech. Dev. 2006, 123, 674-688. [CrossRef] [PubMed]

63. Nieuwkoop, P.; Faber, J. (Eds.) Normal Table of Xenopus laevis (Daudin): A Systematic and Chronological Survey of the Development from the Fertilized Egg till the End of Metamorphosis; North-Holland Publishing Company: Amsterdam, The Netherlands, 1967; ISBN 978-0815318965.

64. Denver, R.J.; Mirhadi, N.; Phillips, M. Adaptive plasticity in amphibian metamorphosis: Response of Scaphiopus hammondii tadpoles to habitat desiccation. Ecology 1998, 79, 1859-1872. [CrossRef]

65. De Block, M.; Stoks, R. Compensatory growth and oxidative stress in a damselfly. Proc. R. Soc. 2008, 275, 781-785. [CrossRef] [PubMed]

66. Denver, R.J. Proximate mechanisms of phenotypic plasticity in amphibian metamorphosis. Integr. Comp. Biol. 1997, 37, 172-184. [CrossRef]

67. Werner, E.E.; Anholt, B.R. Ecological consequences of the trade-off between growth and mortality rates mediated by foraging activity. Am. Nat. 1993, 142, 242-272. [CrossRef] [PubMed]

68. Wilbur, H.M.; Collins, J.P. Ecological aspects of amphibian metamorphosis. Science 1973, 182, $1305-1314$. [CrossRef] [PubMed]

69. Echeverri, K.; Clarke, J.D.; Tanaka, E.M. In vivo imaging indicates muscle fiber dedifferentiation is a major contributor to the regenerating tail blastema. Dev. Biol. 2001, 236, 151-164. [CrossRef] [PubMed]

70. Schnapp, E.; Kragl, M.; Rubin, L.; Tanaka, E.M. Hedgehog signaling controls dorsoventral patterning, blastema cell proliferation and cartilage induction during axolotl tail regeneration. Development 2005, 132, 3243-3253. [CrossRef] [PubMed]

71. Whited, J.L.; Tabin, C.J. Regeneration review reprise. J. Biol. 2010, 9, 15. [CrossRef]

72. Gargioli, C.; Slack, J.M. Cell lineage tracing during Xenopus tail regeneration. Development 2004, 131, 2669-2679. [CrossRef]

73. Maki, N.; Suetsugu-Maki, R.; Tarui, H.; Agata, K.; Del Rio-Tsonis, K.; Tsonis, P.A. Expression of stem cell pluripotency factors during regeneration in newts. Dev. Dyn. 2009, 238, 1613-1616. [CrossRef] [PubMed]

74. Love, N.R.; Chen, Y.; Bonev, B.; Gilchrist, M.J.; Fairclough, L.; Lea, R.; Mohun, T.J.; Paredes, R.; Zeef, L.A.; Amaya, E. Genome-wide analysis of gene expression during Xenopus tropicalis tadpole tail regeneration. BMC Dev. Biol. 2011, 10, 70. [CrossRef] [PubMed] 
75. Niethammer, P.; Grabher, C.; Look, A.T.; Mitchison, T.J. A tissue-scale gradient of hydrogen peroxide mediates rapid wound detection in zebrafish. Nature 2009, 459, 996-999. [CrossRef] [PubMed]

76. Gauron, C.; Rampon, C.; Bouzaffour, M.; Ipendey, E.; Teillon, J.; Volovitch, M.; Vriz, S. Sustained production of ROS triggers compensatory proliferation and is required for regeneration to proceed. Sci. Rep. 2013, 3, 2084. [CrossRef] [PubMed]

77. Hennings, H.; Michael, D.; Cheng, C.; Steinert, P.; Holbrook, K.; Yuspa, S.H. Calcium regulation of growth and differentiation of mouse epidermal cells in culture. Cell 1980, 19, 245-254. [CrossRef]

78. Mattson, M.P. Apoptosis in neurodegenerative disorders. Nat. Rev. Mol. Cell. Biol. 2000, 1, 120-129. [CrossRef] [PubMed]

79. Chan, D.C. Fusion and fission: Interlinked processes critical for mitochondrial health. Ann. Rev. Genet. 2012, 46, 265-287. [CrossRef] [PubMed]

80. Twig, G.; Shirihai, O.S. The interplay between mitochondrial dynamics and mitophagy. Antioxid. Redox Signal 2011, 14, 1939-1951. [CrossRef] [PubMed]

81. Szabadkai, G.; Simoni, A.M.; Chami, M.; Wieckowski, M.R.; Youle, R.J.; Rizzuto, R. Drp-1-dependent division of the mitochondrial network blocks intraorganellar $\mathrm{Ca}^{2+}$ waves and protects against $\mathrm{Ca}^{2+}$-mediated apoptosis. Mol. Cell 2004, 16, 59-68. [CrossRef]

82. Youle, R.J.; Van Der Bliek, A.M. Mitochondrial fission, fusion, and stress. Science 2012, 337, $1062-1065$. [CrossRef] [PubMed]

83. Rouzier, C.; Bannwarth, S.; Chaussenot, A.; Chevrollier, A.; Verschueren, A.; Bonello-Palot, N.; Fragaki, K.; Cano, A.; Pouget, J.; Pellissier, J.F.; et al. The MFN2 gene is responsible for mitochondrial DNA instability and optic atrophy "plus" phenotype. Brain 2012, 135, 23-34. [CrossRef] [PubMed]

84. McCarron, J.G.; Wilson, C.; Sandison, M.E.; Olson, M.L.; Girkin, J.M.; Saunter, C.; Chalmers, S. From structure to function: Mitochondrial morphology, motion and shaping in vascular smooth muscle. J. Vasc. Res. 2013, 50, 357-371. [CrossRef] [PubMed]

85. Solenski, N.J.; diPierro, C.G.; Trimmer, P.A.; Kwan, A.L.; Helms, G.A. Ultrastructural changes of neuronal mitochondria after transient and permanent cerebral ischemia. Stroke 2002, 33, 816-824. [CrossRef] [PubMed]

86. Srinivasan, B. Mitochondrial permeability transition pore: An enigmatic gatekeeper. New Horiz. Sci. Technol. 1015, 1, 47-51.

87. Fridman, J.S.; Lowe, S.W. Control of apoptosis by p53. Oncogene 2003, 22, 9030-9040. [CrossRef]

88. van der Zand, A.; Gent, J.; Braakman, I.; Tabak, H.F. Biochemically distinct vesicles from the endoplasmic reticulum fuse to form peroxisomes. Cell 2012, 149, 397-409. [CrossRef] [PubMed]

89. Corpas, F.J.; Barroso, J.B.; del Río, L.A. Peroxisomes as a source of reactive oxygen species and nitric oxide signal molecules in plant cells. Trends Plant Sci. 2001, 6, 145-150. [CrossRef]

90. Furuse, M.; Hata, M.; Furuse, K.; Yoshida, Y.; Haratake, A.; Sugitani, Y.; Noda, T.; Kubo, A.; Tsukita, S. Claudin-based tight junctions are crucial for the mammalian epidermal barrier: A lesson from claudin-1-deficient mice. J. Cell Biol. 2002, 156, 1099-1111. [CrossRef]

91. Tattersall, G.J.; Wright, P.A. The effects of ambient $\mathrm{pH}$ on nitrogen excretion in early life stages of the American toad (Bufo americanus). Comp. Biochem. Physiol. A Physiol. 1996, 113, 369-374. [CrossRef]

92. Willens, S.; Stoskopf, M.K.; Baynes, R.E.; Lewbart, G.A.; Taylor, S.K.; Kennedy-Stoskopf, S. Percutaneous malathion absorption by anuran skin in flow-through diffusion cells. Environ. Toxicol. Pharmacol. 2006, 22, 255-262. [CrossRef]

93. Sumigray, K.D.; Lechler, T. Cell adhesion in epidermal development and barrier formation. In Current Topics in Developmental Biology; Yap, A., Ed.; Academic Press: Cambridge, MA, USA, 2015; pp. 383-414. [CrossRef]

(C) 2019 by the authors. Licensee MDPI, Basel, Switzerland. This article is an open access article distributed under the terms and conditions of the Creative Commons Attribution (CC BY) license (http://creativecommons.org/licenses/by/4.0/). 